\title{
A Novel Way of Assessing Plant Vitality in Urban Trees
}

\author{
Patricio Sepúlveda ${ }^{1}$ and Denise M. Johnstone ${ }^{2, *}$ \\ 1 Tanks en Tarpulin, Santiago 6290, Chile; patricio.e.sepulveda@gmail.com \\ 2 School of Ecosystem and Forest Sciences, The University of Melbourne, Melbourne 3010, Australia \\ * Correspondence: denisej@unimelb.edu.au; Tel.: +61-0427-689-495
}

Received: 8 November 2018; Accepted: 19 December 2018; Published: 20 December 2018

\begin{abstract}
The assessment of mature urban tree vitality using physiological measurements is still in its infancy. Chlorophyll fluorescence is a method for assessing tree vitality that has potential for use in urban environments, particularly on trunk bark, which is easy to access from the ground. Here we describe how we compared bark and leaf fluorescence in a variety of street and park trees (Ficus macrophylla Pers., Platanus $\times$ acerifolia (Aiton) Willd., and Ulmus parvifolia Jacq.) with pre-dawn water potential as a way of determining the cause of potential physiological stress in the summer of 2012. Statistical relationships were observed between bark chlorophyll fluorescence and pre-dawn water potential in Ficus macrophylla and Platanus $\times$ acerifolia, but were not as consistent in Ulmus parvifolia. In addition, bark and leaf chlorophyll fluorescence were compared with an urban visual vitality index both in autumn 2011 and summer 2012. In this case statistical relationships between bark chlorophyll fluorescence values and urban tree visual vitality were almost non-existent in the Ficus macrophylla and Platanus $\times$ acerifolia trees, however, statistical relationships were significant between bark chlorophyll fluorescence and the urban tree vitality index in Ulmus parvifolia. Bark chlorophyll fluorescence may become a useful tool for measuring physiological stress in trees, but further work needs to be undertaken to clarify and better understand the varying responses of different tree species.
\end{abstract}

Keywords: bark chlorophyll fluorescence; stress physiology; visual vitality

\section{Introduction}

Healthy trees offer a broad set of benefits to the urban environment [1]. However, urban trees can be affected by many environmental stresses commonly found in cities such as limited sunlight, poor soil fertility, soil compaction, and limited water availability, in addition to problems that may also affect forest trees, such as pests and biotic diseases [2,3]. Depending on the persistence and intensity of these stressors, tree growth, health, and ultimately life span can be reduced [3]. When changes in environmental conditions exceed the limit of tolerance, the structure and function of the plant cells and organs may be damaged, affecting their capacity to maintain and preserve their vital functions [4]. In order to deliver these benefits, urban trees not only have to maintain their health or vigor by resisting prevailing environmental conditions, but they also need to display significant vitality. Shigo [5] defined vitality as the ability to grow under existing conditions, as differentiated from tree vigor, which is the genetic capacity of trees to resist strain. As Johnstone et al. [6] stated, "tree vitality can be defined with reference to the stress to which a plant has been exposed; low vitality trees will not respond to treatments designed to ameliorate physiological stress, due perhaps to extremely low or depleted carbohydrate reserves, whereas high vitality trees will respond positively to treatment".

However, tree vitality is a theoretical concept that cannot be directly measured, which is why it has been commonly described using tree health indicators [3]. Measurements of the starch and 
glucose contents of trees, cambial electrical resistance at breast height, chlorophyll content of leaves, and leaf gas exchange are some examples of physiological tests used to estimate plant vitality [6]. Measuring leaf water potential $\left(\Psi_{\mathrm{W}}\right)$ is the most common parameter used to assess the water status of plants. When a plant is dehydrated, its water potential decreases [7]. Leaf, and sometimes stem, water potentials are measured in a pressure chamber. The pressure is increased around a leaf until xylem sap appears at the end of the shoot where the cut end is exposed to atmospheric pressure [8]. The pressure exerted in order for the xylem sap to come out of the stem represents the negative pressure existing in the intact stem [8]. It is believed that the amount of pressure required to force water out of leaf cells into xylem is a function of the water potential of leaf cells [8]. Pre-dawn water potentials measure the minimum level of stress that a plant is experiencing, while midday levels indicate the maximum level of water stress [9].

Since all the raw materials and energy necessary to obtain optimal wood formation are primarily obtained from the reduction of carbon dioxide, photosynthesis is also an essential physiological process in tree growth [10]. Chlorophyll fluorescence measurement is therefore another an important physiological tool, which has been used to detect and quantify plant responses to stress by giving information of the efficiency of the leaf photosynthetic system [11-13]. However aside from a few studies, the most common way of measuring chlorophyll fluorescence continues to be via the leaves, which can be difficult to access.

The energy lost by chlorophyll fluorescence is considered an indicator of a less efficient photosynthetic capacity of plants, which can ultimately affect the health of trees [14]. Fluorometric techniques have come into use during the last two decades to study photosynthetic processes, and have been recently applied to numerous studies in plant stress physiology, agriculture, forestry, and horticulture [15]. According to these authors, the introduction of portable and user-friendly fluorometers has been one the main drivers behind the increasing use of this technique to measure plant physiology in the field.

Fluorescence is usually measured on leaves over a 1-s time period after darkening the leaf and occurs as a result of photosystem II (PS II), which is the first part of the light-dependent reactions of photosynthesis [10]. The resultant graph of fluorescence over time is log-transformed, resulting in a "polyphasic fluorescence transient" moving through various stages, usually labelled $\mathrm{O}, \mathrm{J}$, I, and $\mathrm{P}$ at various time intervals within the 1-s time period [12]. For example, the O-step $\left(\mathrm{F}_{0}\right.$ or fluorescence at origin) is usually measured at around $50 \mu \mathrm{s}$, the J-step $\left(\mathrm{F}_{\mathrm{J}}\right)$ at $2 \mathrm{~ms}$, the I-step $\left(\mathrm{F}_{\mathrm{I}}\right)$ at $30 \mathrm{~ms}$, and the P-step $\left(\mathrm{F}_{\mathrm{P}}, \mathrm{F}_{\mathrm{M}}\right)$ at maximum [16]. The $\mathrm{O}-\mathrm{J}$ phase is believed to represent the reduction of the $\mathrm{Q}_{\mathrm{A}}$ molecule from $Q_{A}$ to $Q_{A}$ - within PSII $[2,16,17]$. The J-I may be fluorescence from the abaxial layer of the sample in some plants, such as Ficus species [17], or both the J-I and I-P phases could reflect the existence of fast and slow reducing plastoquinone centers [2]. $\mathrm{P}$ or $\mathrm{F}_{\mathrm{M}}$ occurs when all the plastoquinone $\mathrm{Q}_{\mathrm{A}}$ electron carrier molecules are in their reduced state $[2,18]$.

The most commonly derived parameter used in chlorophyll fluorescence measurement is $F_{V} / F_{M}$, where $F_{V}$ is the difference between the maximum $\left(F_{M}\right)$ and minimum $\left(F_{0}\right)$ fluorescence [15]. $F_{V} / F_{M}$ is a measure of the quantum efficiency of PSII if all the PSII reaction centers are open [15]. Ideal $F_{V} / F_{M}$ values for non-stressed plants are said to be between 0.78 and 0.85 , with an optimal value of around 0.83 for most plants, although this may not be the case with all Eucalyptus species. [12,15,19]. $\left(1-\mathrm{V}_{\mathrm{J}}\right) / \mathrm{V}_{\mathrm{J}}$ is another fluorescence parameter derived from the raw data. $\left(1-\mathrm{V}_{\mathrm{J}}\right) / \mathrm{V}_{\mathrm{J}}$ represents the ratio of variable fluorescence at the J-step $\left(\mathrm{V}_{\mathrm{J}}=\left(\mathrm{F}_{\mathrm{J}}-\mathrm{F}_{0}\right) /\left(\mathrm{F}_{\mathrm{M}}-\mathrm{F}_{0}\right)\right)[16]$.

The "energy flux theory" from Strasser et al. [20] also allows for the derivation of further fluorescence parameters from the chlorophyll fluorescence transient. These are either phenomenological energy fluxes (per excited cross-section), specific energy fluxes (per $\mathrm{Q}_{\mathrm{A}}$ reducing PSII reaction center) or flux (yield) ratios [16]. An example of a specific energy flux parameter is the absorption flux per reaction center or $\mathrm{RC} / \mathrm{ABS} . \mathrm{RC} / \mathrm{ABS}=\mathrm{M}_{0}\left(1 / \mathrm{V}_{\mathrm{J}}\right)\left(1 /{ }_{\varphi} \mathrm{Po}\right)$, where $\mathrm{M}_{0} \equiv 4\left(\mathrm{~F}_{\mathrm{I}}-\mathrm{F}_{0}\right) /\left(\mathrm{F}_{\mathrm{M}}-\mathrm{F}_{0}\right)$ approximates the initial slope of the fluorescence transient; $\mathrm{ABS}=$ photon flux absorbed by the antenna pigments; and ${ }_{\varphi} \mathrm{Po} \equiv \mathrm{TR}_{0} / \mathrm{ABS}$ $=\left[1-\left(\mathrm{F}_{0} / \mathrm{F}_{\mathrm{M}}\right)\right]=$ maximum quantum yield of primary photochemistry at $\mathrm{t}=0[16]$. 
The PI or the performance index, the "driving force" of photosynthesis, is also sometimes used as a measure for assessing plant vitality via chlorophyll fluorescence [21-23]. The PI has three components: (i) one relates to the density of PSII reaction centers per excited cross-section of samples (ABS/CS or $\mathrm{F}_{0}$ ), (ii) the second component relates to the performance of the light reactions $\left\{\mathrm{TR}_{0} / \mathrm{CS}\right.$ or $\left.1-\left(\mathrm{F}_{\mathrm{V}} / \mathrm{F}_{0}\right) \mathrm{F}_{0}\right\}$, and (iii) the third component relates to the dark Red-Ox reactions $\left\{\mathrm{ET}_{0} / \mathrm{CS}\right.$ or $\left[1-\left(\mathrm{F}_{0}-\mathrm{F}_{\mathrm{M}}\right)\right](1$ $\left.\left.-\mathrm{V}_{\mathrm{J}}\right) \mathrm{F}_{0}\right\}[16,21]$. The PI in the current study $\left(\mathrm{PI}_{\mathrm{CS}}\right)=(\mathrm{ABS} / \mathrm{CS})\left(\mathrm{TR}_{0} / \mathrm{CS}\right)\left(\mathrm{ET}_{0} / \mathrm{CS}\right)=$ performance index on cross-section basis at $\mathrm{t}=0$ where $\mathrm{CS}=$ excited cross-section, $\mathrm{TR}_{0}=$ trapped energy flux, and $\mathrm{ET}_{0}=$ electron transport flux [16,24]. Apparent rates of photosynthetic electron transport (ETR), non-photochemical quenching (NPQ), and a number of other parameters can be also be derived from the fluorescence kinetic [25].

In an early study conducted by Melcarek and Brown [26], measurements of fluorescence transients performed on leaves of Robinia pseudoacacia L. and Ficus elastica Roxb. trees were sensitive to decreased temperature. Using $\mathrm{F}_{\mathrm{V}} / \mathrm{F}_{\mathrm{M}}$, Adams et al. [27] determined that photosynthetic capacity in leaves of Platanus occidentalis L. remained at a high level during the natural course of autumnal senescence. Drought stress effects on willow leaves (Salix L. sp.) were also measured by Ögren [28] but there was no correlation between $\mathrm{F}_{\mathrm{V}} / \mathrm{F}_{\mathrm{M}}$ and water potential measurements. Similar results were obtained in a study conducted by Epron and Dreyer [29], where $\mathrm{F}_{\mathrm{V}} / \mathrm{F}_{\mathrm{M}}$ measured on the leaves of a 30-year-old stand of Quercus robur L. and Qercus petraea (Matt.) Liebl. remained constant during imposed drought treatments. The effect of urban stress factors on the leaf chlorophyll fluorescence of Platanus acerifolia L. trees was measured by Hermans et al. [30], and a high correlation between aerial morphological observations and $\mathrm{PI}_{\mathrm{ABS}}$ estimations was found. Performance index (PI) values calculated on leaves of Fagus sylvatica L., Fraxinus excelsior L., Abies alba Mill., Picea abies (L.) H.Karst., and Prunus serotina Ehrh. from different provenances showed a variety of responses under different wind conditions and between seasons [31]. Percival et al. [32] used $\mathrm{F}_{\mathrm{V}} / \mathrm{F}_{\mathrm{M}}, \mathrm{CO}_{2}$ fixation and chlorophyll content to identify differences in drought tolerance within the Fraxinus L. genus. The effect of a saline stress on mangrove seedlings growth (Rhizophora mangle L.) were estimated using the $\mathrm{F}_{\mathrm{V}} / \mathrm{F}_{\mathrm{M}}$ ratio and stomatal conductance measurements by Biber [33]. Rasineni, Guha, and Reddy [34] used OJIP-test parameters to study the effects of high atmospheric $\mathrm{CO}_{2}$ concentrations on the photosynthesis capacity of Gmelina arborea Roxb.

In addition to physiological measurements, visual assessment estimations have also been applied to determine vitality in trees. Among these, the ground-based visual assessment of crown condition (e.g., crown defoliation, epicormic growth, crown depth and size, leaf condition, and foliage density) has been the most commonly used tool to assess tree vitality [35]. Many studies have highlighted the use of crown assessment techniques as a reliable indicator of vitality in forest stands [1,35-38]. A crown assessment or urban visual vitality index used by Callow et al. [39] was modified from Johnstone et al. [12] which was derived from Martin et al. [38], who combined crown assessment methods from both Grimes [37] and Lindenmayer et al. [40]. Grimes' [37] method incorporates a score for crown position in relation to other trees, crown size, crown density, the number of dead branches, and epicormic growth. This author found that each of five variables contributed significantly to a prediction equation for diameter at breast height, but for better results each factor should be weighted differently. For example, epicormic growth should be weighted on a three-point scale and crown density on a nine-point scale. Lindenmayer et al. [40] assessed hollows in trees and thus included a dead tree classification. Visual assessment or condition/vigor "indices" use a wide range of parameters-with some individual components that are not independent of each other. Those with fewer individual parameters seem to more accurately reflect growth measurements such as stem diameter or tree height.

Cunningham et al. [36] maintained that few attempts have been made to relate commonly used visual assessments of tree vitality to more accurate physiological measurements of tree health. However, visual injury observations were found to be highly correlated with lower values of performance index (PI) in the ozone-exposed leaves of Fagus sylvatica L. trees [41]. Using correlation 
analysis, Rossini et al. [42] compared several chlorophyll fluorescence parameters $\left(\mathrm{F}_{0}, \mathrm{~F}_{\mathrm{M}}, \mathrm{F}_{\mathrm{V}} / \mathrm{F}_{\mathrm{M}}\right.$, and PI) with visual discoloration indices obtained from 10 stands of Quercus robur L. trees. Only the PI value correlated with visual discoloration in this study [42]. Martínez-Trinidad [43] used leaf chlorophyll fluorescence $\mathrm{F}_{\mathrm{V}} / \mathrm{F}_{\mathrm{M}}$ to determine the vitality of live oaks (Quercus virginiana Mill.) in an urban forest, and found an inverse correlation between this parameter and different categories of visual vitality. Johnstone et al. [12] found a positive correlation between leaf chlorophyll fluorescence $\left(\mathrm{F}_{\mathrm{V}} / \mathrm{F}_{\mathrm{M}}\right)$ and visual vitality in Eucalyptus saligna $\mathrm{Sm}$., but only during a period of immediate stress (summer). Autumn and spring measurements did not show a correlation between leaf $F_{V} / F_{M}$ and visual vitality [12].

Despite the advantages of chlorophyll fluorescence as a measure of tree vitality, there are some disadvantages. For example, it is sometimes difficult and time-consuming to access the upper canopy of tall trees to sample leaves. Several studies also found that some leaf chlorophyll fluorescence parameters such as $\mathrm{F}_{\mathrm{V}} / \mathrm{F}_{\mathrm{M}}$ are not very responsive to stress conditions [44-46]. Many trees have plant parts other than leaves that can photosynthesize. Examples of plant parts that may contain the chlorenchyma that enable photosynthesis are stems, trunks, green flowers and fruit, and sometimes even wood [47]. Bark photosynthesis measurements have been used to measure the overall participation of corticular photosynthesis in the fixation of carbon in trees [47-49]. In addition, corticular photosynthesis may also prevent oxygen deficiencies in rapidly dividing woody tissues [50]. The transpirational xylem stream supplies nutrients to stem chlorenchyma, while the $\mathrm{CO}_{2}$ from mitochondrial respiration and gaseous xylem efflux is utilized for photosynthetic processes [51]. Tausz et al. [52] determined that bark on the sun-exposed side of Eucalyptus nitens can experience photoinhibition, measuring variations between diurnal and nocturnal $\mathrm{F}_{\mathrm{V}} / \mathrm{F}_{\mathrm{M}}$ measurements. Wittmann and Pfanz [53] found that $\mathrm{F}_{\mathrm{V}} / \mathrm{F}_{\mathrm{M}}$ values calculated in 1-2-year-old stems of Fagus sylvatica L. and Betula pendula Roth showed slow responses to moderate changes in temperature, but drastically decreased at freezing temperatures $\left(<5^{\circ} \mathrm{C}\right)$. In a study conducted by Johnstone et al. [12], bark and leaf $\mathrm{F}_{\mathrm{V}} / \mathrm{F}_{\mathrm{M}}$ ratio and OJIP steps measured in a Eucalyptus saligna Sm. plantation were compared and correlated with visual vitality indices over three seasons. The results of this study showed important evidence of a relationship between bark chlorophyll fluorescence $F_{V} / F_{M}$ and the visual assessment of vitality. Additional work by the same authors indicated a relationship between wood decay and bark fluorescence [54].

Comparing this arsenal of tools for the assessment of physiological stress in mature urban Ficus macrophylla, Platanus $\times$ acerifolia, and Ulmus parvifolia trees, we here report how we tested the following hypotheses:

1. There is a relationship between pre-dawn water potential and leaf chlorophyll fluorescence;

2. There is a relationship between crown condition (the visual vitality index) and leaf chlorophyll fluorescence;

3. There is a relationship between the visual vitality index and chlorophyll fluorescence measured in the bark of the trunk;

4. There is a relationship between pre-dawn water potential and chlorophyll fluorescence measured in the bark of the trunk.

We took chlorophyll fluorescence measurements of leaves and bark during summer and investigated the relationship of these factors with pre-dawn water potentials. We also took chlorophyll fluorescence measurements of leaves and bark over two seasons and investigated the relationship of these with a visual vitality index.

\section{Materials and Methods}

This study used Ficus macrophylla Pers. (park trees planted in an avenue) and street tree plantations of Platanus $\times$ acerifolia (Aiton) Willd. and Ulmus parvifolia Jacq. in the city of Melbourne, Australia $\left(144^{\circ} 58^{\prime} 0^{\prime \prime} \mathrm{S} ; 37^{\circ} 49^{\prime} \mathrm{E}\right)$. The Ficus macrophylla and Platanus $\times$ acerifolia were approximately $20-25 \mathrm{~m}$ and 
the Ulmus parvifolia were slightly smaller trees at around $15 \mathrm{~m}$, but all trees were mature specimens. In this investigation bark and leaf chlorophyll fluorescence measurements were compared to pre-dawn water potential measurements in summer (January 2012). Bark and leaf chlorophyll fluorescence measurements were compared with an urban visual vitality index in autumn (March 2011) and summer (January 2012). Pre-dawn water potentials were also compared with the urban visual vitality index in summer (January 2012). Forty trees of each species were chosen for the study as that number has been proven to provide successful correlations between bark chlorophyll fluorescence and visual vitality in a study of trees in a rural plantation [12].

\subsection{Pre-Dawn Water Potential}

Leaf water potential was measured by harvesting five leaves from within the upper half of the crown of each tree. As the Platanus $\times$ acerifolia and Ficus macrophylla trees were tall, leaves were harvested with a hydraulic lift tower in the morning-between 6 a.m. and 7 a.m., depending on the season-prior to direct sunlight reaching the canopy. Leaves from the smaller Ulmus parvifolia trees were harvested using a pole pruner, also between 6 a.m. and 7 a.m. depending on the season. Water potential measurements were taken in a PMS Model 1000 pressure chamber (PMS instrument company, Albany, OR, USA), within 20 min of leaf harvesting. Leaf water potential was measured using the protocol first described by Scholander [55].

\subsection{Leaf Chlorophyll Fluorescence Measurements}

Leaf chlorophyll fluorescence was measured on fully exposed sun leaves from upper branches on the trees with a Hansatech Handy Plant Efficiency Analyzer (Handy PEA, Hansatech Instruments, King's Lynn, Norfolk, UK). As the Platanus $\times$ acerifolia and Ficus macrophylla trees were tall $(20-25 \mathrm{~m})$, branches approximately $5 \mathrm{~mm}$ in diameter were harvested with a hydraulic lift tower in the morning, between 6 a.m. and 8 a.m. depending on the season. Leaves from the smaller Ulmus parvifolia trees (approximately $15 \mathrm{~m}$ ) were harvested using a pole pruner, also between 6 a.m. and 8 a.m. depending on the season. A saturating flash of red light onto the leaf after the period of darkness induced a time-dependent fluorescence kinetic known as the Kautsky effect on the leaf chlorophyll [56,57]. Ten leaves from each tree were dark-acclimated for $30 \mathrm{~min}$ with leaf clips in the autumn 2011 season. Both dark acclimation and the duration of darkening sensitivity were measured for all three tree species for the summer dataset in 2012, according to protocols described in the Handy PEA manual [24]. The duration of darkening for all three tree species in leaf chlorophyll fluorescence was measured to be $30 \mathrm{~min}$. The peak wavelength of the saturating pulse of the Handy PEA was $650 \mathrm{~nm}$ [24]. The saturated light level of the instrument was set at $1500 \mu \mathrm{mol} \mathrm{m}^{-2} \mathrm{~s}^{-1}$, with the signal gain at $\times 1.0$ for the autumn 2011 season. After the sensitivity of bark and leaf chlorophyll to light intensity was assessed for the summer 2012 season, the Platanus $\times$ acerifolia leaf tissues were measured at $2000 \mu \mathrm{mol} \mathrm{m}^{-2} \mathrm{~s}^{-1}$, Ficus macrophylla at $2500 \mu \mathrm{mol} \mathrm{m} \mathrm{m}^{-2} \mathrm{~s}^{-1}$, and Ulmus parvifolia at $3000 \mu \mathrm{mol} \mathrm{m} \mathrm{m}^{-2} \mathrm{~s}^{-1}$. For all trees, the signal gain was set at $\times 1$.0. All trees were tested within $2-3 \mathrm{~h}$ of being harvested, as recommended by Epron and Dreyer [29].

Bark chlorophyll fluorescence testing was done in a 350-mm strip in cross-section at the north (most sun-exposed) half of the trunk, with individual measurement points $35 \mathrm{~mm}$ apart, as described in Johnstone et al. [12]. Ten tests were conducted on each tree after being dark-acclimated for $30 \mathrm{~min}$ in the autumn 2011 season. Both dark acclimation and the duration of darkening sensitivity were measured for all three tree species for the summer dataset in 2012, according to protocols described in the manual [24]. Bark chlorophyll fluorescence testing was conducted between 6 a.m. and 8 a.m. in summer and autumn. A flash of red light onto the bark again induced the time-dependent fluorescence kinetic known as the Kautsky effect on the bark chlorenchymes [56,57]. The saturated light level of the instrument was set at $1500 \mu \mathrm{mol} \mathrm{m} \mathrm{m}^{-2} \mathrm{~s}^{-1}$, with the signal gain at $\times 1.0$ for the autumn 2011 season. After the sensitivity of bark chlorophyll to light intensity was assessed for the summer 2012 season, the Platanus $\times$ acerifolia bark tissues were measured at $2000 \mu \mathrm{mol} \mathrm{m}{ }^{-2} \mathrm{~s}^{-1}$, 
Ficus macrophylla, at $3500 \mu \mathrm{mol} \mathrm{m}{ }^{-2} \mathrm{~s}^{-1}$, and Ulmus parvifolia at $3000 \mu \mathrm{mol} \mathrm{m}{ }^{-2} \mathrm{~s}^{-1}$. For all trees, the signal gain was set at $\times 1.0$. Measuring bark fluorescence as a method for assessing tree vitality was found by Johnstone et al. [12] to be promising in Eucalyptus saligna. However, one of the possible drawbacks of the measurement was that chlorophyll fluorescence may not reach the true "maximum". Therefore, bark fluorescence in summer was measured over a 1-s period, as it is normally with leaves, but an additional measurement was taken over a 2-s time period to attempt to capture the true "maximum". In every other respect the 1-s measurements were identical to the 2-s measurements.

The bark was not damaged or removed in any way. Areas of bark damaged, decorticating, or recently exposed were excluded from testing. No lichen or algae were observed to be present. The height at which trees were measured was variable, as it was necessary to measure above or below rough or damaged bark.

The chlorophyll fluorescence data were averaged from each tree in each tissue (bark and leaf) and in each season. The $\mathrm{F}_{\mathrm{V}} / \mathrm{F}_{\mathrm{M}}$ ratio was calculated from the raw chlorophyll fluorescence data in summer and autumn. There are also many other derived parameters that can be calculated from significant points in the 1- or 2-s time period as chlorophyll fluorescence data is collected from chlorenchyma tissue. Some of these include PI ( $\left.\mathrm{PI}_{\mathrm{CS}}\right), \mathrm{RC} / \mathrm{ABS}, \mathrm{Fv} / \mathrm{F}_{0}$, and $\left(1-\mathrm{V}_{\mathrm{J}}\right) / \mathrm{V}_{\mathrm{J}}$. The PI value was calculated for both autumn and summer while $\mathrm{RC} / \mathrm{ABS}, \mathrm{Fv} / \mathrm{F}_{0}$, and $\left(1-\mathrm{V}_{\mathrm{J}}\right) / \mathrm{V}_{\mathrm{J}}$ were calculated for the summer data collection period.

\subsection{Urban Tree Visual Vitality Index}

The urban tree visual vitality index is a method created by Callow et al. [39] based originally on a method for assessing mature forest trees by Grimes [37] and a method for assessing dead and dying trees by Lindenmayer et al. [40]. Grimes' [37] method was further developed by Martin et al. [38] and Johnstone et al. [12] and finally refined by Callow et al. [39]. The method incorporates three individual scores for (1) crown size, (2) crown density, and (3) crown epicormic growth (Figure 1; [39]). Each attribute can be assigned any number within the appropriate range, whether described directly in the diagram or not. As with the method used by Martin et al. [38], scores were totaled to give an estimate of the urban tree visual vitality of the tree and scores have a nominal range between 1 and 17 . Trees with values at or below 10 have very low visual vitality.

Crown size:
5 - Full
3 - Moderate
1 - Very sparse

Crown Density:
9 - Very dense
7 - Dense
5 - Average
3 - Sparse
1 - Very Sparse

Crown Epicormic Growth:
3 - Nil
2.5 - Slight
- Moderate
1.5 - Severe
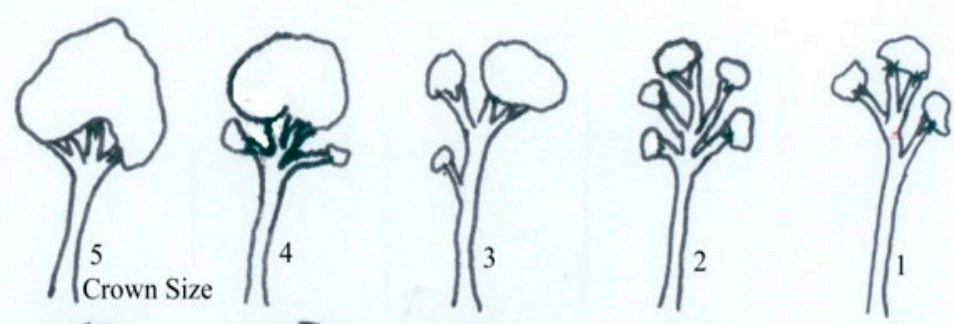

Crown Density:

9 - Very dense

7 - Dense

3 - Sparse

1 - Very Sparse
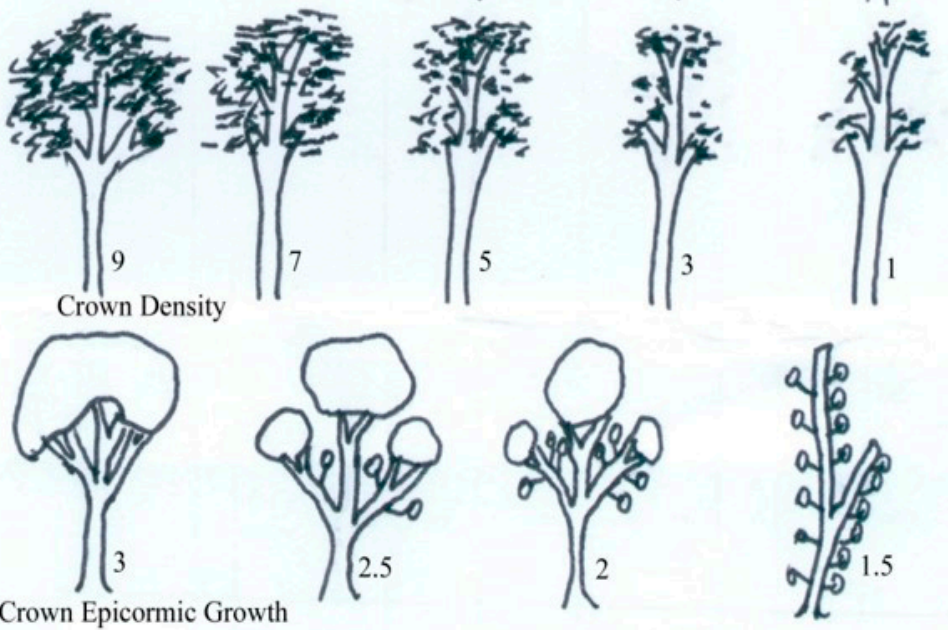

Crown Epicormic Growth:

- Nil

odera

1.5 - Severe

Crown Epicormic Growth
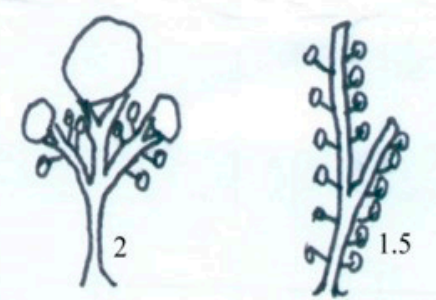

Figure 1. Diagrammatic representation of the urban tree visual vitality index for plantation eucalypts used in this study from Callow et al. [39]. Reproduced with permission from the authors. 
Summer data were compared with pre-dawn water potential measurements, which were collected in January 2012. The urban tree visual vitality index was assessed in the trees in autumn (March 2011) and summer (January 2012).

\subsection{Statistical Analysis of Data}

A comparison was made between summer chlorophyll fluorescence data and summer pre-dawn water potentials using simple linear regression analysis. Also, a comparison was made between autumn and summer chlorophyll fluorescence data and the autumn and summer urban tree visual vitality index using simple linear regression analysis. Linear regression analyses were calculated using the software package SAS (Statistical Analysis System) version 9.2 (SAS Institute Inc, Cary, NC, USA).

For the summer data where $\mathrm{F}_{\mathrm{V}} / \mathrm{F}_{\mathrm{M}}$ was less than 0.6 or where PI was negative, the data were deleted to ensure that readings were not taken in locally damaged bark or leaf tissue. Outlying values greater than two standard deviations from the next lowest result were also removed from the summer data.

\section{Results}

\subsection{Leaf Chlorophyll Fluorescence and Leaf Water Potentials}

There were no statistically significant relationships between leaf chlorophyll fluorescence parameters and pre-dawn water potentials in either Ficus macrophylla or Plantanus $\times$ acerifolia (Table 1). There was a statistically significant relationship between leaf chlorophyll fluorescence and pre-dawn water potentials in Ulmus parvifolia in the $\mathrm{F}_{0}$ parameter and in summer only (Table 1).

Table 1. Summarized results from simple linear regression analyses comparing summer leaf fluorescence with pre-dawn water potentials in Ficus macrophylla, Platanus $\times$ acerifolia, and Ulmus parvifolia.

\begin{tabular}{cccccccccc}
\hline \multirow{2}{*}{ Comparisons } & \multicolumn{3}{c}{ Ficus macrophylla } & \multicolumn{3}{c}{ Platanus $\times$ acerifolia } & \multicolumn{3}{c}{ Ulmus parvifolia } \\
\cline { 2 - 10 } & $\boldsymbol{n}$ & $\boldsymbol{p}$ & $\boldsymbol{r}^{\mathbf{2}}$ & $\boldsymbol{n}$ & $\boldsymbol{p}$ & $\boldsymbol{r}^{\mathbf{2}}$ & $\boldsymbol{n}$ & $\boldsymbol{p}$ & $\boldsymbol{r}^{\mathbf{2}}$ \\
\hline Summer PDWP vs. leaf $\mathrm{F}_{0}$ & 39 & 0.162 & 0.052 & 40 & 0.267 & 0.032 & 39 & $0.005^{\mathrm{a}}$ & 0.192 \\
Summer PDWP vs. leaf $\mathrm{F}_{\mathrm{V}} / \mathrm{F}_{\mathrm{M}}$ & 40 & 0.569 & 0.009 & 40 & 0.642 & 0.006 & 40 & 0.756 & 0.003 \\
Summer PDWP vs. leaf $\mathrm{RC} / \mathrm{ABS}$ & 40 & 0.486 & 0.013 & 40 & 0.573 & 0.008 & 40 & 0.782 & 0.002 \\
Summer PDWP vs. leaf $\mathrm{F}_{\mathrm{V}} / \mathrm{F}_{0}$ & 40 & 0.793 & 0.002 & 40 & 0.780 & 0.002 & 40 & 0.616 & 0.007 \\
Summer PDWP vs. leaf $\left(1-\mathrm{V}_{\mathrm{J}}\right) / \mathrm{V}_{\mathrm{J}}$ & 40 & 0.619 & 0.007 & 40 & 0.413 & 0.018 & 40 & 0.884 & 0.001 \\
Summer PDWP vs. leaf PI & 40 & 0.686 & 0.005 & 40 & 0.573 & 0.008 & 40 & 0.926 & 0.001 \\
\hline
\end{tabular}

${ }^{a}$ statistical relationship is significant and positive; $n=$ number of samples; $p=$ probability for the $t$-test that the coefficient of the independent variable is equal to zero; $r^{2}=$ variation in the dependent variable that can be explained by fluorescence data.

\subsection{Leaf Chlorophyll Fluorescence and the Urban Visual Vitality Index}

There were no statistically significant relationships between autumn leaf chlorophyll fluorescence data and the urban tree visual vitality index in Ficus macrophylla (Table 2). Relationships between some chlorophyll fluorescence parameters and the urban tree visual vitality index in Ficus macrophylla were present in summer only in the $(1-\mathrm{Vj}) / \mathrm{Vj}$ and PI parameters (Table 2). Platanus $\times$ acerifolia displayed significant relationships with the urban tree visual vitality index in autumn, particularly for the $F_{0}$ value (Table 2). The most consistent relationships for leaf chlorophyll fluorescence parameters and the urban tree visual vitality index were in Ulmus parvifolia, in both autumn and summer (Table 2 and Figure 2). 
Table 2. Summarized results from simple linear regression analyses comparing autumn and summer leaf fluorescence with autumn and summer urban tree visual vitality index in Ficus macrophylla, Platanus $\times$ acerifolia, and Ulmus parvifolia.

\begin{tabular}{cccccccccc}
\hline Comparisons & \multicolumn{3}{c}{ Ficus macrophylla } & \multicolumn{3}{c}{ Platanus $\times$ acerifolia } & \multicolumn{3}{c}{ Ulmus parvifolia } \\
\cline { 2 - 10 } & $\boldsymbol{n}$ & $\boldsymbol{p}$ & $\boldsymbol{r}^{\mathbf{2}}$ & $\boldsymbol{n}$ & $\boldsymbol{p}$ & $\boldsymbol{r}^{2}$ & $\boldsymbol{n}$ & $\boldsymbol{p}$ & $\boldsymbol{r}^{\mathbf{2}}$ \\
\hline Autumn UVVI vs. leaf $\mathrm{F}_{0}$ & 40 & 0.654 & 0.005 & 40 & $0.002^{\mathrm{a}}$ & 0.235 & 40 & $<0.000^{\mathrm{a}}$ & 0.296 \\
Autumn UVVI vs. leaf $\mathrm{F}_{\mathrm{V}} / \mathrm{F}_{\mathrm{M}}$ & 40 & 0.7669 & 0.002 & 40 & 0.487 & 0.013 & 40 & $0.006^{\mathrm{a}}$ & 0.181 \\
Autumn UVVI vs. leaf $\mathrm{PI}$ & 40 & 0.867 & 0.001 & 40 & $0.007^{\mathrm{b}}$ & 0.117 & 40 & $<0.000^{\mathrm{a}}$ & 0.310 \\
Summer UVVI vs. leaf $\mathrm{F}_{0}$ & 38 & 0.094 & 0.076 & 40 & 0.814 & 0.002 & 39 & $<0.000^{\mathrm{a}}$ & 0.436 \\
Summer UVVI vs. leaf $\mathrm{F}_{\mathrm{V}} / \mathrm{F}_{\mathrm{M}}$ & 39 & 0.084 & 0.079 & 40 & 0.062 & 0.089 & 40 & 0.064 & 0.088 \\
Summer UVVI vs. leaf RC/ABS & 39 & 0.051 & 0.099 & 40 & 0.163 & 0.051 & 40 & $<0.000^{\mathrm{a}}$ & 0.435 \\
Summer UVVI vs. leaf $\mathrm{F}_{\mathrm{V}} / \mathrm{F}_{0}$ & 39 & 0.063 & 0.090 & 40 & 0.101 & 0.069 & 40 & $0.098^{2}$ & 0.070 \\
Summer UVVI vs. leaf $\left(1-\mathrm{V}_{\mathrm{J}}\right) / \mathrm{V}_{\mathrm{J}}$ & 39 & $0.038^{\mathrm{a}}$ & 0.116 & 40 & 0.103 & 0.069 & 40 & $<0.000^{\mathrm{a}}$ & 0.420 \\
Summer UVVI vs. leaf $\mathrm{PI}$ & 39 & $0.030^{\mathrm{a}}$ & 0.122 & 40 & 0.217 & 0.040 & 40 & $0.000^{\mathrm{a}}$ & 0.322 \\
\hline
\end{tabular}

${ }^{a}$ statistical relationship is significant and positive; ${ }^{b}$ statistical relationship is significant and negative; $n=$ number of samples; $p=$ probability for the $t$-test that the coefficient of the independent variable is equal to zero; $r^{2}=$ variation in the dependent variable that can be explained by fluorescence data.

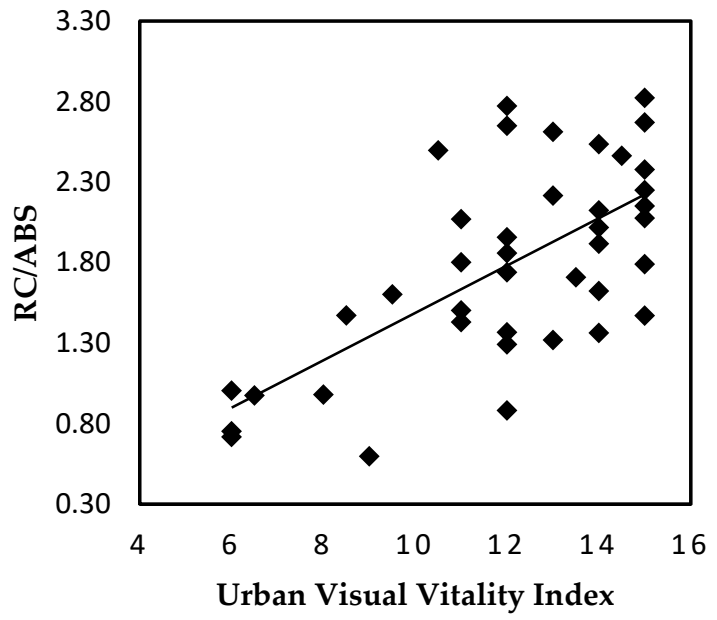

(a)

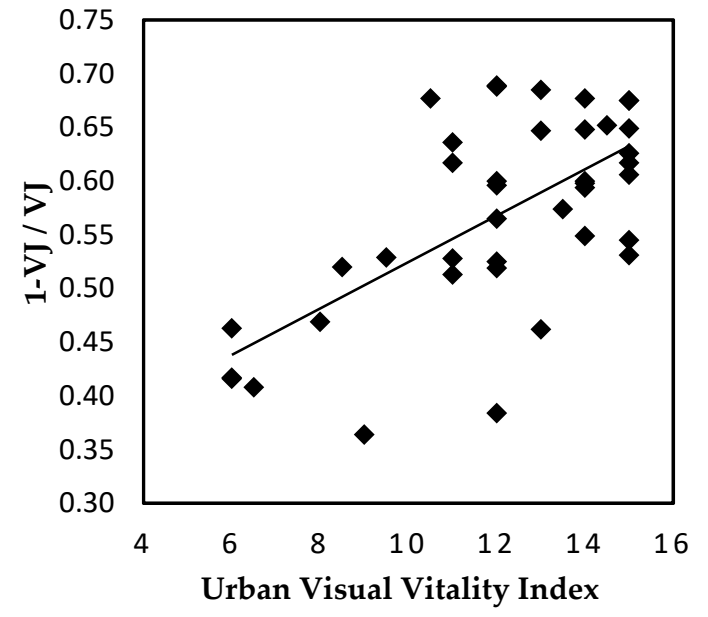

(b)

Figure 2. (a) Summer urban tree visual vitality index versus summer leaf RC/ABS in Ulmus parvifolia. Trend line $=$ linear regression, $p<0.000, r^{2}=0.435, n=40$. (b) Summer urban tree visual vitality index versus summer leaf $(1-\mathrm{Vj}) / \mathrm{Vj}$ in Ulmus parvifolia. Trend line $=$ linear regression, $p<0.000, r^{2}=0.420$, $n=40$.

\subsection{Bark Fluorescence and the Urban Visual Vitality Index}

There was no statistically significant and positive relationship in autumn or summer between bark chlorophyll fluorescence data and the urban tree visual vitality index in Ficus macrophylla (Table 3). There was also no statistically significant relationship between bark chlorophyll fluorescence data and the urban visual vitality index in Platanus $\times$ acerifolia in autumn (Table 3). However, in summer there was a statistically significant and negative relationship between bark $\mathrm{F}_{\mathrm{V}} / \mathrm{F}_{\mathrm{M}}$ and the urban tree visual vitality index in Platanus $\times$ acerifolia when there was a 2-s light exposure. As for the leaf data, the most consistent statistically significant relationships for bark chlorophyll fluorescence parameters and the urban tree visual vitality index were in Ulmus parvifolia in both autumn and summer (Table 3 and Figure 3). 
Table 3. Summarized results from simple linear regression analyses comparing autumn and summer bark fluorescence with autumn and summer urban tree visual vitality index. Linear regressions using the $95 \%$ confidence interval.

\begin{tabular}{cccccccccc}
\hline Comparisons & \multicolumn{3}{c}{ Ficus macrophylla } & \multicolumn{3}{c}{ Platanus $\times$ acerifolia } & \multicolumn{3}{c}{ Ulmus parvifolia } \\
\cline { 2 - 10 } & $\boldsymbol{n}$ & $\boldsymbol{p}$ & $\boldsymbol{r}^{\mathbf{2}}$ & $\boldsymbol{n}$ & $\boldsymbol{p}$ & $\boldsymbol{r}^{\mathbf{2}}$ & $\boldsymbol{n}$ & $\boldsymbol{p}$ & $\boldsymbol{r}^{\mathbf{2}}$ \\
\hline Autumn UVVI vs. bark $\mathrm{F}_{0}$ & 40 & 0.518 & 0.011 & 40 & 0.572 & 0.008 & 40 & 0.976 & $<0.001$ \\
Autumn UVVI vs. bark $\mathrm{F}_{\mathrm{V}} / \mathrm{F}_{\mathrm{M}}$ & 40 & 0.512 & 0.011 & 40 & 0.518 & 0.011 & 40 & 0.590 & 0.008 \\
Autumn UVVI vs. bark PI & 40 & 0.431 & 0.016 & 40 & 0.257 & 0.034 & 40 & $0.003^{\mathrm{a}}$ & 0.204 \\
Summer UVVI vs. bark $\mathrm{F}_{0}(1)$ & 29 & 0.836 & 0.002 & 40 & 0.701 & 0.004 & 32 & 0.573 & 0.011 \\
Summer UVVI vs. bark $\mathrm{F}_{\mathrm{V}} / \mathrm{F}_{\mathrm{M}}(1)$ & 29 & 0.420 & 0.024 & 40 & 0.989 & 0.000 & 32 & $0.007^{\mathrm{a}}$ & 0.221 \\
Summer UVVI vs. bark RC/ABS $(1)$ & 29 & 0.386 & 0.028 & 40 & 0.385 & 0.020 & 32 & $0.019^{\mathrm{a}}$ & 0.170 \\
Summer UVVI vs. bark $\mathrm{F}_{\mathrm{V}} / \mathrm{F}_{0}(1)$ & 29 & 0.530 & 0.015 & 40 & 0.972 & 0.000 & 32 & $0.004^{\mathrm{a}}$ & 0.251 \\
Summer UVVI vs. bark $\left(1-\mathrm{V}_{\mathrm{J}}\right) / \mathrm{V}_{\mathrm{J}}(1)$ & 29 & 0.063 & 0.121 & 40 & 0.667 & 0.005 & 32 & $0.016^{\mathrm{a}}$ & 0.178 \\
Summer UVVI vs. bark PI $(1)$ & 29 & 0.159 & 0.072 & 40 & 0.382 & 0.020 & 31 & $0.001^{\mathrm{a}}$ & 0.314 \\
Summer UVVI vs. bark $\mathrm{F}_{0}(2)$ & 28 & 0.647 & 0.008 & 39 & 0.665 & 0.005 & 32 & 0.367 & 0.027 \\
Summer UVVI vs. bark $\mathrm{F}_{\mathrm{V}} / \mathrm{F}_{\mathrm{M}}(2)$ & 28 & 0.057 & 0.132 & 39 & $0.038^{\mathrm{b}}$ & 0.112 & 32 & $0.030^{\mathrm{a}}$ & 0.148 \\
Summer UVVI vs. bark RC/ABS $(2)$ & 28 & 0.551 & 0.014 & 39 & 0.921 & 0.000 & 32 & 0.285 & 0.038 \\
Summer UVVI vs. bark $\mathrm{F}_{\mathrm{V}} / \mathrm{F}_{0}(2)$ & 28 & 0.055 & 0.134 & 39 & 0.378 & 0.021 & 32 & $0.007^{\mathrm{a}}$ & 0.220 \\
Summer UVVI vs. bark $\left(1-\mathrm{V}_{\mathrm{J}}\right) / \mathrm{V}_{\mathrm{J}}(2)$ & 28 & 0.306 & 0.040 & 39 & 0.178 & 0.049 & 32 & $0.048^{\mathrm{a}}$ & 0.125 \\
Summer UVVI vs. bark PI $(2)$ & 28 & 0.186 & 0.066 & 39 & 0.976 & 0.000 & 31 & 0.073 & 0.103 \\
\hline
\end{tabular}

${ }^{a}$ Statistical relationship is significant and positive; ${ }^{b}$ Statistical relationship is significant and negative; (1), 1-s light exposure; (2), 2-s light exposure; $n=$ number of samples; $p=$ probability for the $t$-test that the coefficient of the independent variable is equal to zero; $r^{2}=$ variation in the dependent variable that can be explained by fluorescence data.

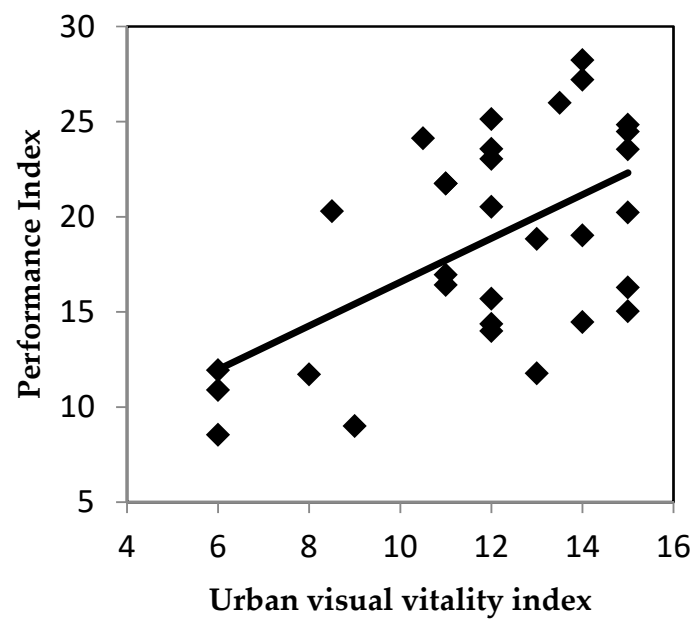

(a)

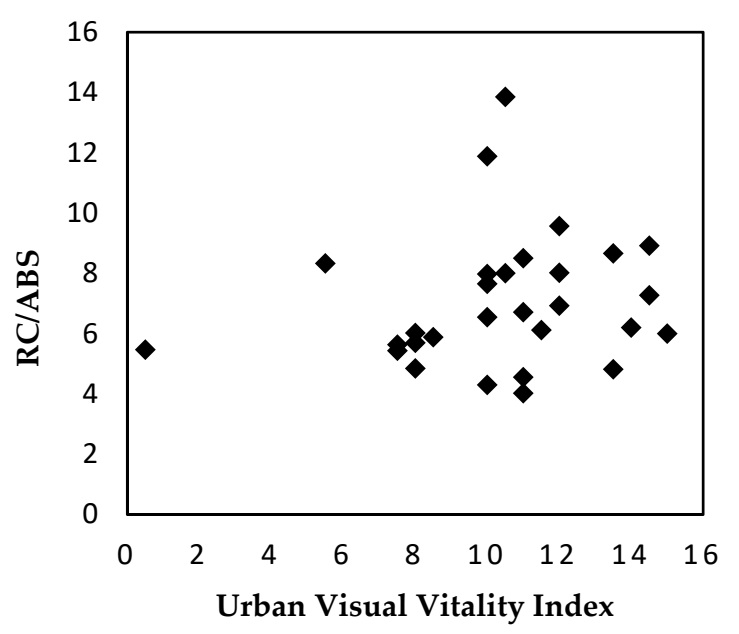

(b)

Figure 3. (a) Summer urban tree visual vitality index versus summer bark PI in Ulmus parvifolia. Trend line $=$ linear regression, $p=0.001, r^{2}=0.314, n=31$. (b) Summer urban tree visual vitality index versus summer bark RC/ABS in Ficus macrophylla. $p=0.386, r^{2}=0.028, n=29$.

\subsection{Bark Fluorescence and Pre-Dawn Water Potentials}

There was a statistically significant and positive relationship between bark chlorophyll fluorescence and pre-dawn water potentials in Ficus macrophylla, particularly in the $(1-\mathrm{Vj}) / \mathrm{Vj}$ and the PI parameters (Table 4; Figure 4). There was a statistically significant and negative relationship between some bark chlorophyll fluorescence parameters and pre-dawn water potentials in Platanus $\times$ acerifolia (Table 4). In Ulmus parvifolia there was a statistically significant and positive relationship between bark $\mathrm{F}_{\mathrm{V}} / \mathrm{F}_{\mathrm{M}}$ and pre-dawn water potentials when there was a 2-s light exposure (Table 4). 
Table 4. Summarized results from simple linear regression analyses comparing summer bark fluorescence with pre-dawn water potentials. Linear regressions using the $95 \%$ confidence interval.

\begin{tabular}{cccccccccc}
\hline \multirow{2}{*}{ Comparisons } & \multicolumn{3}{c}{ Ficus macrophylla } & \multicolumn{3}{c}{ Platanus $\times$ acerifolia } & \multicolumn{3}{c}{ Ulmus parvifolia } \\
\cline { 2 - 10 } & $\boldsymbol{n}$ & $\boldsymbol{p}$ & $\boldsymbol{r}^{\mathbf{2}}$ & $\boldsymbol{n}$ & $\boldsymbol{p}$ & $\boldsymbol{r}^{\mathbf{2}}$ & $\boldsymbol{n}$ & $\boldsymbol{p}$ & $\boldsymbol{r}^{\mathbf{2}}$ \\
\hline Summer PDWP vs. bark $\mathrm{F}_{0}(1)$ & 29 & 0.079 & 0.110 & 40 & 0.893 & 0.000 & 32 & 0.945 & 0.000 \\
Summer PDWP vs. bark $\mathrm{F}_{\mathrm{V}} / \mathrm{F}_{\mathrm{M}}(1)$ & 29 & 0.460 & 0.020 & 40 & 0.954 & 0.000 & 32 & 0.156 & 0.066 \\
Summer PDWP vs. bark RC/ABS (1) & 29 & $0.045^{\mathrm{a}}$ & 0.141 & 40 & 0.359 & 0.022 & 32 & 0.240 & 0.046 \\
Summer PDWP vs. bark $\mathrm{F}_{\mathrm{V}} / \mathrm{F}_{0}(1)$ & 29 & 0.398 & 0.027 & 40 & 0.447 & 0.015 & 32 & 0.178 & 0.060 \\
Summer PDWP vs. bark $\left(1-\mathrm{V}_{\mathrm{J}}\right) / \mathrm{V}_{\mathrm{J}}(1)$ & 29 & $0.001^{\mathrm{a}}$ & 0.325 & 40 & 0.627 & 0.006 & 32 & 0.986 & 0.000 \\
Summer PDWP vs. bark PI (1) & 29 & $0.007^{\mathrm{a}}$ & 0.238 & 40 & 0.605 & 0.007 & 32 & 0.345 & 0.031 \\
Summer PDWP vs. bark $\mathrm{F}_{0}(2)$ & 29 & 0.207 & 0.058 & 39 & 0.945 & 0.000 & 32 & 0.979 & 0.000 \\
Summer PDWP vs. bark $\mathrm{F}_{\mathrm{V}} / \mathrm{F}_{\mathrm{M}}(2)$ & 29 & 0.515 & 0.016 & 39 & $0.048^{\mathrm{b}}$ & 0.101 & 32 & $0.046^{\mathrm{a}}$ & 0.127 \\
Summer PDWP vs. bark RC/ABS (2) & 29 & 0.538 & 0.014 & 39 & 0.080 & 0.081 & 32 & 0.758 & 0.003 \\
Summer PDWP vs. bark $\mathrm{F}_{\mathrm{V}} / \mathrm{F}_{0}(2)$ & 29 & 0.476 & 0.019 & 39 & $0.038^{\mathrm{b}}$ & 0.112 & 32 & 0.059 & 0.114 \\
Summer PDWP vs. bark $\left(1-\mathrm{V}_{\mathrm{J}}\right) / \mathrm{V}_{\mathrm{J}}(2)$ & 29 & 0.066 & 0.120 & 39 & $0.046^{\mathrm{b}}$ & 0.104 & 32 & 0.921 & 0.000 \\
Summer PDWP vs. bark PI $(2)$ & 29 & 0.254 & 0.048 & 39 & 0.066 & 0.089 & 32 & 0.362 & 0.028 \\
\hline
\end{tabular}

${ }^{a}$ statistical relationship is significant and positive; ${ }^{b}$ statistical relationship is significant and negative; (1), 1-s light exposure; (2), 2-s light exposure; $n=$ number of samples; $p=$ probability for the $t$-test that the coefficient of the independent variable is equal to zero; $r^{2}=$ variation in the dependent variable that can be explained by fluorescence data.

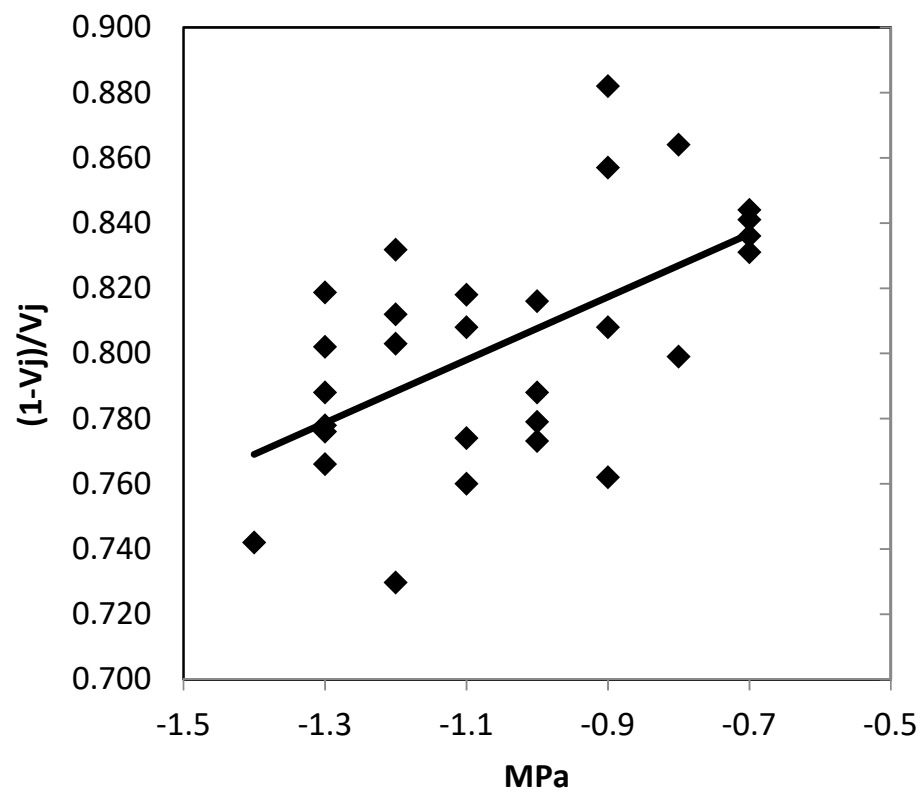

Figure 4. Summer pre-dawn water potential versus summer bark $(1-\mathrm{Vj}) / \mathrm{Vj}$ in Ficus macrophylla. Trend line $=$ linear regression, $p=0.001, r^{2}=0.325, n=29$.

\subsection{Urban Visual Vitality Index and Pre-Dawn Water Potential}

There was no statistically significant relationship between the urban visual vitality index and pre-dawn water potential in Ficus macrophylla and Ulmus parvifolia. However, there was a statistically significant and negative relationship between visual vitality and pre-dawn water potential in Platanus $\times$ acerifolia (Figure $5 ; n=40, p=0.001, r^{2}=0.240$ ). Values for pre-dawn water potential were not measured in autumn. 


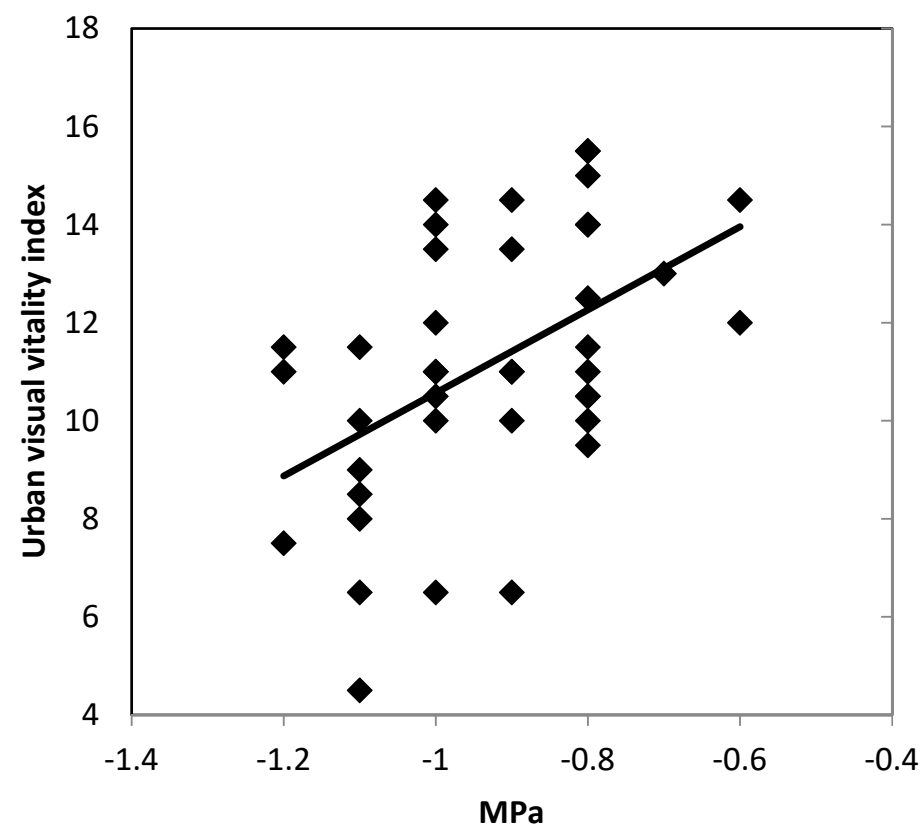

Figure 5. Summer pre-dawn water potential versus urban visual vitality index in Platanus $\times$ acerifolia. Trend line $=$ linear regression, $p=0.001, r^{2}=0.240, n=40$.

\section{Discussion}

The assessment of tree vitality is a crucial activity that urban tree managers must regularly perform in order to develop effective plans to maintain mature trees. Compared with the visual examination of crown condition, the use of chlorophyll fluorescence measurements could help urban foresters to obtain a more accurate estimation of vitality, mainly by giving information on how the process of photosynthesis is affected by urban environmental stresses [46,58]. In this study, leaf and bark chlorophyll fluorescence measurements and pre-dawn water potentials were collected from mature specimens of three common tree species planted in Melbourne, and then compared with the visual vitality index to determine the reliability of this technique to predict mature tree vitality. Comparisons using leaf chlorophyll fluorescence measurements are discussed initially and then the discussion moves to bark chlorophyll fluorescence measurements.

The relationships between leaf chlorophyll florescence and water potential were only measured in one season (summer) and they were not consistent between species (Table 1). The average pre-dawn water potential for Platanus $\times$ acerifolia in this study was $-0.9 \mathrm{MPa}$. The turgor loss point in Platanus orientalis L. was found to be $-2.2 \mathrm{MPa}$ in a previous study (in summer) [59]. There is a high likelihood that the Platanus $\times$ acerifolia in this study were not moisture-stressed, leading to the lack of correlation found between water potential and leaf chlorophyll florescence.

The average pre-dawn water potential for Ficus macrophylla in this study was $-1.0 \mathrm{MPa}$. Similar species of figs in one study found turgor loss points between -1.5 MPa and -1.2 MPa [60]. Many figs appear to be adapted to high water use [60]. Therefore, they use close their stomata when drought-stressed, rather than exhibiting acclimations that allow for very low turgor loss points [61]. It is therefore not clear whether the Ficus macrophylla in this study were moisture-stressed using only pre-dawn water potential measurements. Hence, an apparent lack of correlation between leaf chlorophyll florescence measurements and water potential in Ficus macrophylla was observed (Table 1).

There was a positive correlation between summer leaf $\mathrm{F}_{0}$ chlorophyll fluorescence and water potential in Ulmus parvifolia, meaning that higher $\mathrm{F}_{0}$ values were associated with leaves that were less drought-stressed (Table 1). The average water potential of the measured Ulmus parvifolia was $-0.7 \mathrm{MPa}$. Turgor loss point in Ulmus parvifolia has been found to be at around -1.6 MPa [62], indicating that the Ulmus parvifolia may have been experiencing mild drought stress. According to the literature, higher 
values of $F_{0}$ usually indicate damage to PSII [14], and have been frequently associated to foliar damage after controlled stress applications in several tree species [2,32,63], which is the inverse of the result found in the current study. However, Bussotti et al. [63], found a similar inverse association between $\mathrm{F}_{0}$ values and foliar damage when woody species Fagus sylvatica L. and Acer pseudoplatanus L. were exposed to ozone stress. A reduction in $\mathrm{F}_{0}$ values in response to salt exposure was also reported by Percival et al. [64] in several Acer L. genotypes. This response has been explained as a compensative process, in which the PSII of cells surrounding those that have been damaged by environmental stresses are activated [65]. According to Bussotti et al. [63], this plant response to stress might also be explained by a strategy that many plant species use to protect their leaves, which consists in the isolation of damaged cells with a protective layer. $\mathrm{F}_{0}$ has also been found to be highly variable among species, even between sun and shade leaves of the same plant [17], which is why some authors have alluded to some difficulties in using this parameter as an indicator of photosynthetic function [19].

A similar inverse (unexpected) relationship was found between leaf $\mathrm{PI}_{\mathrm{ABS}}$ and the autumn visual vitality index estimated in Platanus $\times$ acerifolia (Table 2$)$. The performance index $\left(\mathrm{PI}_{\mathrm{ABS}}\right)$ is defined as the ratio between the energy be used in photosynthetic activities, and the energy that is dissipated as heat or not used for the electron transport within photosynthesis [31]. Therefore, higher $\mathrm{PI}_{\mathrm{ABS}}$ values would be expected in visually healthier trees, but these inverse associations have also been reported in other investigations. Rossini et al. [42] compared chlorophyll fluorescence variables with visual discoloration and defoliation indices in a Quercus robur L. forest, obtaining a negative correlation between both variables. Because variations in the photosynthetic performance in response to stress are rapidly detected by this parameter, the authors stated that discoloration changes could be observed long after low measurements of $\mathrm{PI}_{\mathrm{ABS}}$ are obtained. Martinez-Trinidad [46] also found an inverse relationship between visual observations of health condition and $\mathrm{F}_{\mathrm{V}} / \mathrm{F}_{\mathrm{M}}$ measurements in Quercus virginiana Mill., explaining these results as a possible compensation process from mature leaves in visually declining trees. In the same vein, Bussotti et al. [66] proposed that an increase of photosynthetic performance in plants under stressful conditions might be a product of a "compensation and acclimation" response of leaves, which may largely vary within the crown of the same tree. However, the uncertainty about how stressed the Platanus $\times$ acerifolia were in this study makes it difficult to adopt the compensation process as an explanation for the results of this study.

Unlike the significant relationships found between the visual vitality index and the values obtained on leaves for $\mathrm{F}_{0}$ and $\mathrm{PI}_{\mathrm{ABS}}, \mathrm{F}_{\mathrm{V}} / \mathrm{F}_{\mathrm{M}}$ did not seem to reflect the same variations observed in the visual vitality index estimated in Platanus $\times$ acerifolia. This parameter has been the most widely used to estimate physiological conditions of plants [15] and has also been demonstrated to be more reliable than the level of fluorescence $\left(\mathrm{F}_{0}, \mathrm{~F}_{\mathrm{M}}\right)$ because its values are less dependent on species and other factors, such the chlorophyll content of leaves [19]. Several authors have proposed threshold values to categorized health condition of analyzed plants, ranging from 0.76 to 0.83 for healthy trees [14,32]. However, the average values of $\mathrm{F}_{\mathrm{V}} / \mathrm{F}_{\mathrm{M}}$ obtained in this study from Platanus $\times$ acerifolia were always over 0.80 , even in trees with low visual vitality scores. For Cunningham et al. [36], the unreliability of $\mathrm{F}_{\mathrm{V}} / \mathrm{F}_{\mathrm{M}}$ to reflect visual variations of the crown condition in stands of Eucalyptus camaldulensis Dehnh. was explained mostly by the different factors that could affect crown condition, such as age, size, and tree location. In the current study, variables such crown size, for example, may be affected by tree pruning regimes, and might not be necessarily associated with any change in the physiological condition of the tree. Hence, some trees may have received a low score in the visual vitality index (for crown size in particular) but this may not necessarily imply that these trees were physiologically less vital. The intrinsic capacity of a particular species to maintain adequate levels of photosynthetic capacity despite visual alterations in crown condition was suggested by Johnstone et al. [12] as a possible explanation for similar results for leaf $F_{V} / F_{M}$ versus the visual vitality index in Eucalyptus saligna Sm. Similar limitations also exist in the current study, as Platanus $\times$ acerifolia are very tolerant to a range of environmental stresses. 
The lack of correlation between leaf chlorophyll fluorescence parameters and visual estimations of vitality in Ficus macrophylla are difficult to explain. Differences in optical properties of leaves between species, and sometimes within the same plant (e.g., leaf thickness and chlorophyll content), as well as low light availability (full-sun leaves or shaded leaves) may lower leaf chlorophyll fluorescence emissions $[17,19]$. Therefore, the greater thickness of the leaves of Ficus macrophylla and the dim light conditions under which the sampled leaves were growing (leaves were collected from the inner canopy of selected trees) were first thought to be possible explanations for the null relationships found between chlorophyll fluorescence parameters and the estimated visual vitality index. However, the plotted rise of chlorophyll fluorescence for this species showed similar and even higher levels of fluorescence when compared with those of Platanus $\times$ acerifolia and Ulmus parvifolia. A simpler explanation of these results may be the advantageous conditions under which the studied Ficus macrophylla specimens were growing (Falkner Park). Park conditions, unlike streets and roads, present less stressful conditions for plant growth. Therefore, despite some selected specimens of this species showed visual signs of low vitality, these could have been product of the suppression of neighboring trees (trees were closely spaced in a double row avenue) and not necessarily a response of a lower physiological vitality. In fact, and similar to what happened in Platanus $\times$ acerifolia trees, $\mathrm{F}_{\mathrm{V}} / \mathrm{F}_{\mathrm{M}}$ values rarely dropped below 0.80 even though there was more variation in visual estimations of the Ficus macrophylla trees than in the Platanus $\times$ acerifolia trees.

The absence of consistent statistical relationships between leaf chlorophyll florescence and tree vitality in Ficus macrophylla and Plantanus $\times$ acerifolia with regard to many chlorophyll florescence parameters, including $\mathrm{F}_{\mathrm{V}} \mathrm{F}_{\mathrm{M}}$, may reflect the fact that low vitality is related to lower total leaf mass, which means that stress-affected trees have to support fewer leaves. Leaf tissues appear to remain relatively "vital" under such conditions. Similar results were obtained in a study by Martinez-Trinidad et al. [46] when measuring mature Quercus virginiana Mill. They suggested that low vitality Quercus virginiana may support fewer, but more efficiently operating, leaves.

The presence of photosynthetic active tissue below the periderm of stems and branches has made it possible to measure photosynthesis in these parts of the tree [52]. However, bark chlorophyll fluorescence has not been widely used to estimate stress response in woody plants apart, from a study by Johnstone et al. [12]. The results obtained from the comparisons between visual estimations of vitality and calculated bark chlorophyll fluorescence parameters showed a null result in Ficus macrophylla (Table 3). In summer there was a statistically significant and negative relationship between bark $\mathrm{F}_{\mathrm{V}} / \mathrm{F}_{\mathrm{M}}$ and the urban tree visual vitality index in Platanus $\times$ acerifolia when there was a 2-s light exposure, but no correlations were observed in autumn (Table 3). This result is the reverse of the expected relationship, as discussed later. In terms of the null result in autumn, some authors have proposed that bark thickness could limit the penetration of light into stems, thus lowering the resultant fluorescence signal [12,48]. Damesin [48] estimated that in 1-year-old stems of Fagus sylvatica L., only $20 \%$ of incident light is transmitted through external bark, and compared with leaf values, bark $\mathrm{F}_{\mathrm{V}} / \mathrm{F}_{\mathrm{M}}$ values were always lower throughout the year. These lower bark fluorescence signals can also be observed in plotted fast fluorescence rise for the three species in the current study, where values of raw fluorescence emission from bark were half those obtained in leaf samples, in agreement with the study of Eucalyptus saligna Sm. by Johnstone et al. [12]. Modifications of actinic light settings (time and intensity) for the measurement of bark chlorophyll florescence in future studies may help to clarify whether anatomic differences between species (bark thickness) are responsible for the lower chlorophyll fluorescence signals obtained in this study.

However, as the significant relationships with the urban tree vitality index show, bark chlorophyll fluorescence seemed to be as responsive as leaf chlorophyll fluorescence to a decline in tree vitality suffered by Ulmus parvifolia (Tables 2 and 3, Figures 2 and 3). This result is consistent with results recorded by Johnstone et al. [12] in Eucalyptus saligna Sm. In another study, leaf chlorophyll fluorescence was found to be less sensitive to long-term drought than stem chlorophyll fluorescence in Alnus glutinosa (L.) Gaertn. (black alder), Prunus avium (L.) L. (wild cherry), Quercus robur L. (English 
oak), Betula pendula Roth (silver birch), and Fagus sylvatica L. (European beech) [67]. The stems showed greater sensitivity to drought stress than leaves, even though the stems took longer to show any effect of drying in the first instance [67]. Chlorophyll fluorescence was measured on woody tissue by Percival [68] on freeze-stressed Betula pendula Roth (silver birch) after being bare-rooted prior to transplanting in the field. Seventeen weeks after planting, the freeze-dried Betula pendula saplings had significantly different bark chlorophyll fluorescence measurements compared to those not subjected to the stress, which was also highly correlated to height increment and foliar damage [68]. These results are consistent with the current study, where there was a statistical relationship between bark chlorophyll fluorescence and the urban tree vitality index in Ulmus parvifolia.

It has been suggested that the lower intensity of bark photosynthesis, due to the lower intensity of saturated light reaching the chlorenchyma of stems, makes the photosynthesis process less dependent on environmental factors and the occurrence of photodegradation more unlikely $[52,69]$. Tausz et al. [52] determined that bark on the sun-exposed side of Eucalyptus nitens Maiden can experience photoinhibition, finding variations between diurnal and nocturnal $\mathrm{F}_{\mathrm{V}} / \mathrm{F}_{\mathrm{M}}$ measurements. Wittmann and Pfanz [53] determined that $\mathrm{F}_{\mathrm{V}} / \mathrm{F}_{\mathrm{M}}$ values calculated in 1-2-year-old stems of Fagus sylvatica L. and Betula pendula Roth showed slow response to moderate changes in temperature, but drastically decreased at freezing temperatures $\left(<5^{\circ} \mathrm{C}\right)$. In a recent study conducted in stands of Eucalyptus saligna $\mathrm{Sm}$., bark $\mathrm{F}_{\mathrm{V}} / \mathrm{F}_{\mathrm{M}}$ measured in summer and autumn showed a statistical relationship with visual estimations of tree vitality [12]. In the present study, the positive relationship found between bark PI and the visual vitality index estimated in Ulmus parivifolia in autumn, as well as several chlorophyll fluorescence parameters in summer, provided evidence of corticular photoinhibition in this species. The photosynthetic performance index is a multiparametric expression that has demonstrated to be more sensitive to changes in energy fluctuation during the process of photosynthesis than some other parameters used in this study $[30,33,66]$. In fact, the performance index value in leaves has been shown to be more sensitive to drought stress than the more commonly used $F_{V} / F_{M}$ parameter [21,70-72]

It is important to highlight that Ulmus parvifolia specimens presented more variation in crown condition than the other tree species tested, and the signs of visually lower vitality were also more evident. Therefore, it is possible that the selected Ulmus parvifolia specimens may have been under stressful conditions at the moment of measurement, and the effect on photosynthesis capacity was not only clearly detected by simple observation, but also more easily detected by leaf and bark chlorophyll fluorescence parameters.

As mentioned earlier, in summer there was a statistically significant and negative relationship between bark $\mathrm{F}_{\mathrm{V}} / \mathrm{F}_{\mathrm{M}}$ and the urban tree visual vitality index in Platanus $\times$ acerifolia when there was a 2-s light exposure. This result is the reverse of the expected relationship. In summer there was also a statistically significant and positive relationship between bark $F_{V} / F_{M}$ and pre-dawn water potential in Ulmus parvifolia when there was a 2-s light exposure. This is also the reverse of the expected relationship. These results are difficult to explain, although inconsistent or an unexplained result where leaf chlorophyll fluorescence is concerned is not unheard of, as with the previously mentioned research by Martinez-Trinidad et al. [46]. In addition, the bark chlorophyll fluorescence measurements using a 2-s light exposure rather than a 1-s light exposure did not always increase the $\mathrm{F}_{\mathrm{M}}$ or "maximum" chlorophyll fluorescence. As there appears to be no published research on the duration of light exposure with regard to chlorophyll fluorescence maximum, it is difficult to speculate as to why an increased duration does not consistently increase $F_{M}$ (data not shown).

On the other hand, consistent and significant statistical relationships were found between bark chlorophyll fluorescence and pre-dawn water potentials in Ficus macrophylla and Plantanus $\times$ acerifolia but not Ulmus parvifolia (Table 4, Figure 4). This suggests that the studied Ficus macrophylla and Plantanus $\times$ acerifolia trees were under immediate moisture stress, whereas the studied Ulmus parvifolia trees had been under a longer-term period of stress, which would be consistent with symptoms of reduced visual vitality in the crown. 
There was no statistically significant relationship between the urban visual vitality index and pre-dawn water potential in Ficus macrophylla and Ulmus parvifolia. However, there was a statistically significant and negative relationship between visual vitality and pre-dawn water potential in Platanus $\times$ acerifolia. This suggests that the visual vitality index method of assessing crown condition could be indicative of drought stress in Platanus $\times$ acerifolia, in agreement with the data collected from Ulmus by Callow et al. [39]. Values for pre-dawn water potential were not measured in autumn.

\section{Conclusions}

We found little evidence for our first hypothesis that there is a relationship between leaf water potential and leaf chlorophyll fluorescence in mature trees. With respect to the second hypothesis-whether there is a relationship between the visual vitality index and leaf chlorophyll fluorescence-we found evidence of this with regard to all three mature tree species; Ficus macrophylla, Platanus $\times$ acerifolia, and Ulmus parvifolia. We found good evidence for a relationship between bark chlorophyll fluorescence and the visual vitality index in mature Ulmus parvifolia, but not in Ficus macrophylla or Platanus $\times$ acerifolia, which only partially supports our third hypothesis. Somewhat surprisingly, we did find evidence to support our hypothesis that there is a relationship between leaf water potential and bark chlorophyll fluorescence in mature Ficus macrophylla and Platanus $\times$ acerifolia, but not in Ulmus parvifolia.

It appears that bark chlorophyll fluorescence measurements may offer a useful tool for tree vitality and/or assessment of the water status of individual mature urban tree species. However, further work is required to confirm the usefulness of bark chlorophyll fluorescence in this context.

Author Contributions: Conceptualization, D.M.J.; Methodology, D.M.J.; Formal analysis, P.S. and D.M.J.; Investigation, P.S. and D.M.J.; Resources, D.M.J.; Data curation, P.S. and D.M.J.; Writing—original draft preparation, P.S. and D.M.J.; Writing—review and editing, D.M.J.; Supervision, D.M.J.; Project administration, D.M.J.; Funding acquisition, D.M.J.

Funding: This research was partially funded by The TREE Fund, grant number 10-JK-02.

Acknowledgments: The authors would like to thank David Callow and Beau Picking for assistance in data collection. We would also like to thank the city of Melbourne for assistance with data collection, equipment, and the use of mature trees for testing. In addition, we thank Tree Logic for the use of equipment essential to the project and The University of Melbourne for administrative support.

Conflicts of Interest: The authors declare no conflict of interest. The funders had no role in the design of the study; in the collection, analyses, or interpretation of data; in the writing of the manuscript, or in the decision to publish the results.

\section{References}

1. Wargo, P.M.; Minocha, R.; Wong, B.L.; Long, R.P.; Horsley, S.B.; Hall, T.J. Measuring changes in stress and vitality indicators in limed sugar maple on the Allegheny plateau in north-central Pennsylvania. Can. J. For. Res. 2002, 32, 629-641. [CrossRef]

2. Percival, G. The use of chlorophyll fluorescence to identify chemical and environmental stress in leaf tissue of three oak (Quercus) species. J. Arboric. 2005, 31, 215-227.

3. Dobbertin, M. Tree growth as indicator of tree vitality and of tree reaction to environmental stress: A review. Eur. J. For. Res. 2005, 124, 319-333. [CrossRef]

4. Larcher, W. Physiological Plant Ecology: Ecophysiology and Stress Physiology of Functional Groups, 4th ed.; Springer: Berlin, Germany, 2003.

5. Shigo, A.L. A New Tree Biology; Shigo and Trees: Durham, UK, 1986; p. 132.

6. Johnstone, D.; Moore, G.; Tausz, M.; Nicolas, M. The measurement of plant vitality in landscape trees. Arboric. J. 2013, 35, 18-27. [CrossRef]

7. Kramer, P.; Boyer, J. Water Relations of Plants and Soils; Academic Press: San Diego, CA, USA, 1995; p. 495.

8. Kirkham, M. Principles of Soil and Plant Water Relations; Elsevier Academic Press: New York, NY, USA, 2005; p. 500.

9. Beadle, C.L. Physiology of eucalypts in relation to disease. In Diseases and Pathogens of Eucalypts; Keane, P., Kile, G., Podger, F., Brown, B., Eds.; CSIRO Publishing: Melbourne, Australia, 2000; pp. 61-70. 
10. Kozlowski, T. Growth and development of trees. In Cambial Growth, Root Growth and Reproductive Growth; Academic Press: New York, NY, USA, 1971; Volume 2, p. 514.

11. Roháček, K.; Soukupová, J.; Barták, M. Chlorophyll fluorescence: A wonderful tool to study plant physiology and plant stress. Res. Signpost India 2008, 37/661, 41-104.

12. Johnstone, D.; Tausz, M.; Moore, G.; Nicolas, M. Chlorophyll fluorescence of the trunk rather than leaves indicates visual vitality in Eucalyptus saligna. Trees Struct. Funct. 2012, 26, 1565-1576. [CrossRef]

13. Percival, G.; Fraser, G. Use of sugars to improve root growth and increase transplant success of birch (Betula pendula Roth.). J. Arboric. 2005, 31, 66-77.

14. DeEll, J.; Toivonen, P. Practical Applications of Chlorophyll Fluorescence in Plant Biology; Kluwer Academic: London, UK, 2003; p. 259.

15. Maxwell, K.; Johnson, G.N. Chlorophyll fluorescence-A practical guide. J. Exp. Bot. 2000, 51, 659. [CrossRef]

16. Strasser, R.J.; Tsimilli-Michael, M.; Srivastava, A. Analysis of the chlorophyll a fluorescence transient. In Chlorophyll a Fluorescence. A Signature of Photosynthesis; Papageorgiou, G.C., Govindjee, Eds.; Springer: Dordrecht, The Netherland, 2004; pp. 321-362.

17. Hsu, B.D.; Leu, K.L. A possible origin of the middle phase of polyphasic chlorophyll fluorescence transient. Funct. Plant Biol. 2003, 30, 571-576. [CrossRef]

18. Krause, G.H.; Weis, E. Chlorophyll fluorescence as a tool in plant physiology. Photosynth. Res. 1984, 5, 139-157. [CrossRef]

19. Bjorkman, O.; Demmig, B. Photon yield of o-2 evolution and chlorophyll fluorescence characteristics at 77-k among vascular plants of diverse origins. Planta 1987, 170, 489-504. [CrossRef]

20. Strasser, R.; Srivastava, A.; Tsimilli-Michael, M. The fluorescence transient as a tool to characterize and screen photosynthetic samples. In Probing Photosynthesis: Mechanisms, Regulation and Adaptation; Yunus, M., Pathre, U., Mohanty, P., Eds.; Taylor and Francis: London, UK, 2000; pp. 445-483.

21. Christen, D.; Schönmann, S.; Jermini, M.; Strasser, R.; Défago, G. Characterization and early detection of grapevine (Vitis vinifera) stress responses to esca disease by in situ chlorophyll fluorescence and comparison with drought stress. Environ. Exp. Bot. 2007, 60, 504-514. [CrossRef]

22. Percival, G.C.; AlBalushi, A.M.S. Paclobutrazol-induced drought tolerance in containerized English and evergreen oak. Arboric. Urban For. 2007, 33, 397-409.

23. Swoczyna, T.; Kalaji, H.M.; Pietkiewicz, S.; Borowski, J.; Zaras-Januszkiewicz, E. Photosynthetic apparatus efficiency of eight tree taxa as an indicator of their tolerance to urban environments. Dendrobiology 2010, 63, 65-75.

24. Hansatech Instruments. Operations Manual Handy Pea Pocket Pea and Pea Plus Software; Hansatech Instruments: Norfolk, UK, 2006; p. 85.

25. Lüttge, U.; Berg, A.; Fetene, M.; Nauke, P.; Peter, D.; Beck, E. Comparative characterization of photosynthetic performance and water relations of native trees and exotic plantation trees in an Ethiopian forest. Trees Struct. Funct. 2003, 17, 40-50. [CrossRef]

26. Melcarek, P.; Brown, G. Effects of chill stress on prompt and delayed chlorophyll fluorescence from leaves. Plant Physiol. 1977, 60, 822-825. [CrossRef] [PubMed]

27. Adams, W.; Winter, K.; Schreiber, U.; Schramel, P. Photosynthesis and chlorophyll fluorescence characteristics in relationship to changes in pigment and element composition of leaves of Platanus occidentalis L. during autumnal leaf senescence. Plant Physiol. 1990, 92, 1184-1190. [CrossRef] [PubMed]

28. Ögren, E. Evaluation of chlorophyll fluorescence as a probe for drought stress in willow leaves. Plant Physiol. 1990, 93, 1280-1285. [CrossRef]

29. Epron, D.; Dreyer, E. Long-term effects of drought on photosynthesis of adult oak trees [Quercus petraea (Matt.) Liebl. and Quercus robur L.] in a natural stand. New Phytol. 1993, 125, 381-389. [CrossRef]

30. Hermans, C.; Smeyers, M.; Rodriguez, R.M.; Eyletters, M.; Strasser, R.J.; Delhaye, J.P. Quality assessment of urban trees: A comparative study of physiological characterisation, airborne imaging and on site fluorescence monitoring by the OJIP-test. J. Plant Physiol. 2003, 160, 81-90. [CrossRef]

31. Clark, A.; Landolt, W.; Bucher, J.; Strasser, R. How wind affects the photosynthetic performance of trees: Quantified with chlorophyll a fluorescence and open-top chambers. Photosynthetica 2001, 38, 349-360. [CrossRef]

32. Percival, G.C.; Keary, I.P.; AL-Habsi, S. An assessment of the drought tolerance of Fraxinus genotypes for urban landscape plantings. Urban For. Urban Green. 2006, 5, 17-27. [CrossRef] 
33. Biber, P. Measuring the effects of salinity stress in the red mangrove, Rhizophora mangle L. Afr. J. Agric. Res. 2006, 1, 1-4.

34. Rasineni, G.; Guha, A.; Reddy, A. Elevated atmospheric $\mathrm{CO}_{2}$ mitigated photoinhibition in a tropical tree species, Gmelina arborea. J. Photochem. Photobiol. B Biol. 2011, 103, 159-165. [CrossRef] [PubMed]

35. Coops, N.C.; Stone, C.; Culvenor, D.S.; Chisholm, L. Assessment of crown condition in eucalypt vegetation by remotely sensed optical indices. J. Environ. Qual. 2004, 33, 956-964. [CrossRef] [PubMed]

36. Cunningham, S.C.; Read, J.; Baker, P.J.; Mac Nally, R. Quantitative assessment of stand condition and its relationship to physiological stress in stands of Eucalyptus camaldulensis (Myrtaceae). Aust. J. Bot. 2007, 55, 692-699. [CrossRef]

37. Grimes, R. Crown assessment of natural spotted gum (Eucalyptus maculata), ironbark (Eucalyptus fibrosa, Eucalyptus drepanophylla) forest. Qld. Dep. For. 1978, 7, 1-16.

38. Martin, R.A.U.; Burgman, M.A.; Minchin, P.R. Spatial analysis of eucalypt dieback at Coranderrk, Australia. Appl. Veg. Sci. 2001, 4, 257-266. [CrossRef]

39. Callow, D.; May, P.; Johnstone, D.M. Tree vitality assessment in urban landscapes. Forests 2018, 9, 7. [CrossRef]

40. Lindenmayer, D.; Norton, T.; Tanton, M. Differences between wildfire and clearfelling on the structure of montane ash forests of Victoria and their implications for fauna dependent on tree hollows. Aust. For. 1990, 53, 61-68. [CrossRef]

41. Clark, A.; Landolt, W.; Bucher, J.; Strasser, R. Beech (Fagus sylvatica) response to ozone exposure assessed with a chlorophyll $a$ fluorescence performance index. Environ. Pollut. 2000, 109, 501-507. [CrossRef]

42. Rossini, M.; Panigada, C.; Meroni, M.; Colombo, R. Assessment of oak forest condition based on leaf biochemical variables and chlorophyll fluorescence. Tree Physiol. 2006, 26, 1487-1496. [CrossRef] [PubMed]

43. Martínez-Trinidad, T.; Watson, W.; Arnold, M.; Lombardini, L.; Appel, D. Carbohydrate injections as a potential option to improve growth and vitality of live oaks. Arboric. Urban For. 2009, 35, 142-147.

44. Rodríguez-Calcerrada, J.; Pardos, J.A.; Gil, L.; Reich, P.B.; Aranda, I. Light response in seedlings of a temperate (Quercus petraea) and a Sub-Mediterranean species (Quercus pyrenaica): Contrasting ecological strategies as potential keys to regeneration performance in mixed marginal populations. Plant Ecol. 2008, 195, 273-285. [CrossRef]

45. Contran, N.; Poletti, E.; Manning, W.; Tagliaferro, F. Ozone sensitivity and ethylenediurea protection in ash trees assessed by JIP chlorophyll a fluorescence transient analysis. Photosynthetica 2009, 47, 68-78. [CrossRef]

46. Martinez-Trinidad, T.; Watson, W.T.; Arnold, M.A.; Lombardini, L.; Appel, D.N. Comparing various techniques to measure tree vitality of live oaks. Urban For. Urban Green. 2010, 9, 199-203. [CrossRef]

47. Pfanz, H.; Aschan, G.; Langenfeld-Heyser, R.; Wittmann, C.; Loose, M. Ecology and ecophysiology of tree stems: Corticular and wood photosynthesis. Naturwissenschaften 2002, 89, 147-162.

48. Damesin, C. Respiration and photosynthesis characteristics of current-year stems of Fagus sylvatica: From the seasonal pattern to an annual balance. New Phytol. 2003, 158, 465-475. [CrossRef]

49. Kharouk, V.; Middleton, E.; Spencer, S.; Rock, B.; Williams, D. Aspen bark photosynthesis and its significance to remote sensing and carbon budget estimates in the boreal ecosystem. Water Air Soil Pollut. 1995, 82, 483-497. [CrossRef]

50. Wittmann, C.; Pfanz, H. Bark and woody tissue photosynthesis: A means to avoid hypoxia or anoxia in developing stem tissues. Funct. Plant Biol. 2014, 41, 940-953. [CrossRef]

51. Pfanz, H. Bark photosynthesis. Trees Struct. Funct. 2008, 22, 137-138. [CrossRef]

52. Tausz, M.; Warren, C.R.; Adams, M.A. Is the bark of shining gum (Eucalyptus nitens) a sun or a shade leaf? Trees Struct. Funct. 2005, 19, 415-421. [CrossRef]

53. Wittmann, C.; Pfanz, H. Temperature dependency of bark photosynthesis in beech (Fagus sylvatica L.) and birch (Betula pendula Roth.) trees. J. Exp. Bot. 2007, 58, 4293-4306. [CrossRef] [PubMed]

54. Johnstone, D.; Tausz, M.; Moore, G.; Nicolas, M. Bark and leaf chlorophyll fluorescence are linked to wood structural changes in Eucalyptus saligna. AoB Plants 2014, 6, plt057. [CrossRef] [PubMed]

55. Scholander, P.F.; Hammel, H.; Hemmingsen, E.; Bradstreet, E. Hydrostatic pressure and osmotic potential in leaves of mangroves and some other plants. Proc. Natl. Acad. Sci. USA 1964, 52, 119-125. [CrossRef] [PubMed]

56. Govindjee, G. Chlorophyll a fluorescence: A bit of basics and history. In Chlorophyll a Fluorescence. A Signature of Photosynthesis; Papageorgiou, G.C., Govindjee, G., Eds.; Springer: Dordrecht, The Netherland, 2004; pp. 1-41. 
57. Percival, G.C. Identifying Tree Decline Using "Fluorescence Fingerprinting"; International Society of Arboriculture Australia Chapter: Hobart, Australia, 2005.

58. Maldonado-Rodriguez, R.; Pavlov, S.; Gonzalez, A.; Oukarroum, A.; Strasser, R.J. Can machines recognise stress in plants? Environ. Chem. Lett. 2003, 1, 201-205. [CrossRef]

59. Lo Gullo, M.; Nardini, A.; Trifilò, P.; Salleo, S. Diurnal and seasonal variations in leaf hydraulic conductance in evergreen and deciduous trees. Tree Physiol. 2005, 25, 505-512. [CrossRef]

60. Hao, G.-Y.; Sack, L.; Wang, A.-Y.; Cao, K.-F.; Goldstein, G. Differentiation of leaf water flux and drought tolerance traits in hemiepiphytic and non-hemiepiphytic Ficus tree species. Funct. Ecol. 2010, 24, 731-740. [CrossRef]

61. Bartlett, M.K.; Scoffoni, C.; Sack, L. The determinants of leaf turgor loss point and prediction of drought tolerance of species and biomes: A global meta-analysis. Ecol. Lett. 2012, 15, 393-405. [CrossRef]

62. Ranney, T.G.; Whitlow, T.H.; Bassuk, N.L. Response of five temperate deciduous tree species to water stress. Tree Physiol. 1990, 6, 439-448. [CrossRef]

63. Bussotti, F.; Agati, G.; Desotgiu, R.; Matteini, P.; Tani, C. Ozone foliar symptoms in woody plant species assessed with ultrastructural and fluorescence analysis. New Phytol. 2005, 166, 941-955. [CrossRef] [PubMed]

64. Percival, G.C.; Fraser, G.A.; Oxenham, G. Foliar salt tolerance of Acer genotypes using chlorophyll fluorescence. J. Arboric. 2003, 29, 61-65.

65. Layne, D.; Flore, J. Photosynthetic compensation to partial leaf area reduction in sour cherry. J. Am. Soc. Hortic. Sci. 1992, 117, 279-286.

66. Bussotti, F.; Desotgiu, R.; Cascio, C.; Pollastrini, M.; Gravano, E.; Gerosa, G.; Marzuoli, R.; Nali, C.; Lorenzini, G.; Salvatori, E. Ozone stress in woody plants assessed with chlorophyll a fluorescence. A critical reassessment of existing data. Environ. Exp. Bot. 2011, 73, 19-30. [CrossRef]

67. Wittmann, C.; Pfanz, H. Antitranspirant functions of stem periderms and their influence on corticular photosynthesis under drought stress. Trees Struct. Funct. 2008, 22, 187-196. [CrossRef]

68. Percival, G.C. Evaluation of physiological tests as predictors of young tree establishment and growth. J. Arboric. 2004, 30, 80-91.

69. McLeod, G. Action spectra of light-saturated photosynthesis. Plant Physiol. 1961, 36, 114-117. [CrossRef] [PubMed]

70. Živčák, M.; Brestič, M.; Olšovská, K.; Slamka, P. Performance index as a sensitive indicator of water stress in Triticum aestivum L. Plant Soil Environ. 2008, 54, 133-139.

71. Oukarroum, A.; Schansker, G.; Strasser, R.J. Drought stress effects on photosystem I content and photosystem II thermotolerance analyzed using $\mathrm{Chl}$ a fluorescence kinetics in barley varieties differing in their drought tolerance. Physiol. Plant 2009, 137, 188-199. [CrossRef] [PubMed]

72. Genty, B.; Briantais, J.-M.; Da Silva, J.B. Effects of drought on primary photosynthetic processes of cotton leaves. Plant Physiol. 1987, 83, 360-364. [CrossRef] 